Journal of Education and Vocational Research (ISSN 2221-2590)

Vol. 6, No. 4, pp. 38-44, December 2015

\title{
A Proposed Framework on the Relationship between Islamic Microfinance Related Factors and Women Entrepreneurs Business Performance in Nigeria
}

\author{
Farida Mohammed Shehu, Nor Hayati Binti Ahmad, Al-Hasan Al-Aidaros \\ University Utara Malaysia, Malaysia \\ fmshehu@yahoo.com
}

\begin{abstract}
Microfinance plays a key role in poverty alleviation, employment generation, mitigating rural urban migration, utilization of local resources and raw materials and contributing to the gross domestic product (GDP) of Nigeria. Women, majority of who are poor and engaged in informal/micro, small and medium scale businesses are mostly the target of microfinance institutions. However, women entrepreneurs find it difficult to have access to the products and services of the conventional banks due to their stringent lending requirement. The presence of Islamic banking which promotes the profit and loss sharing (PLS) concept increases the awareness among women entrepreneurs to alternative funding sources. Despite availability of financing options, women entrepreneurs are constrained by their reluctance to use interest based microfinance services. This paper aims to provide a proposed framework that examines the impact of Islamic investment and financing contracts (Murabaha financing and Mudharabah savings) and other microfinance related factors (training, social capital and self-esteem) on women entrepreneurs business performance. Religiosity is a new moderating variable within the framework that is hypothesized to enhance business performance of women entrepreneurs. The proposed framework will fill the gap in Islamic banking and finance studies since the area of Islamic microfinance and the moderating effect of religiosity has not been empirically investigated.
\end{abstract}

Keywords: Microfinance, Islamic banking, religiosity, women entrepreneurs, business performance.

\section{Introduction}

Globally, the interest in women entrepreneurship is linked to the important consideration that women are important forces in the socioeconomic development of a nation (Verheul, Stel \& Thurik, 2006). As indicated by Kiraka, Kobia, and Katwalo (2013), the global ownership of businesses by women has reached 25 to 33 percent. Additionally, it is further indicated that 60 percent of the potential working population is employed in the informal sector in which women control and run majority of the businesses (Fapohunda, 2012). In Nigeria, amid the colonial era (1800-1960), women are in charge of businesses even though these businesses were small scale in nature compared to their male counterparts (Halkias, Nwajiuba, Harkiolakis \& Caracatsanis, 2011). After the colonial period, unfavorable government policies and oil boom resulted in a drastic fall of women actively participating in the casual informal sector (Halkias et al., 2011), rendering many women unemployed (Ekpe, 2012). However, from 1980s, their desire for survival through addressing essential needs became extremely solid and drove them to take part in entrepreneurial activities (Akinwumi, 2000). In Nigeria, women poverty has a strong gender dimension which hampers socioeconomic advancement (Alese, 2013). Berger and Byvinie (2003) reported that majority of the women engaged in small scale businesses did not yield much profit to bring them out of poverty and raise their living standard. Rather, women entrepreneurs are found to have lower sales returns, smaller number of assets, little profit margins and slim chances of survival than their counterparts' enterprises (Shane, 2003). Many of the entrepreneurship programs that are meant to address the needs of women entrepreneurs in Nigeria such as Better Life for Rural Women (BLRW), Agricultural Credit Guarantee Scheme (ACGS), Family and Economic Advancement Program (FEAP), among others have fizzled (Ekpe, 2012).

Having realized the importance of women entrepreneurship, in 2005, the government of Nigeria initiated the microfinance policy to target the economically active and financially dynamic poor through job creation and poverty reduction by 2020 (CBN, 2005). However, in Nigeria, the loans provided by conventional microfinance institutions (MFIs) to the poor women essentially include credit for consumption and meager loans accompanied with high interest to engage in productive activities (Okojie, Monye-Emina, Eghafona, \& 
Ehiakhamen, 2010). The stringent requirements imposed by conventional banks pose constraint to women accessing capital for their businesses. Due to a large number of Muslim microfinance entrepreneurs the microfinance banks have dedicated units to meet the needs of Muslim women entrepreneurs. These units offer modest and reasonable Shariah compatible products and services to address the funding constraints hence, enhance the business performance of women entrepreneurs; consequently help to reduce poverty (Abbas, Abdul Razak, \& Saad, 2014). Islamic microfinance here refers to the Shariah compliant products and services offered by Islamic microfinance institutions (IMFIs) or conventional MFIs. These are micro-credit in the form of Murabaha financing, and micro-savings in the form of Mudharabah savings. Other microfinance related factors include training, social capital and development of personal attributes such as self-esteem. Despite the importance of women entrepreneurship to the economy there are limited studies to the knowledge of the researcher that links together Islamic microfinance related factors to the business performance of women entrepreneurs particularly in Nigeria. The difference in this study compared to other past studies is the inclusion of religiosity as a moderating variable in a proposed framework that will link Islamic microfinance related factors and women entrepreneurs business performance in Nigeria. This paper consists of four sections. The first section is the introduction of the study. The second section is review of literature on Islamic microfinance related factors (Murabaha financing, Mudharabah savings, training, social capital, self-esteem) and religiosity; and women entrepreneurs' business performance. The third section presents the proposed conceptual framework for the study, and section four concludes the paper.

\section{Literature Review}

Women Entrepreneurs Business Performance (WEBP): Women Entrepreneurs Business Performance (WEBP is defined as the performance of the women entrepreneurs in terms of change in output, change in profit, change in investment and change in employment. Earlier studies on women entrepreneurs focused on how gender influences business performance (Chaganti, 1986; Cuba, Decenzo \& Anish, 1983; Hisrich \& Brush, 1987), providing information on characteristics and motivations towards women entrepreneurs' business performance. Those that dwelled on gender comparison include studies such as Holmquist and Sundin (1988), Kalleberg and Leicht (1991) and Johnson and Storey (1993). In some studies, women are meant to achieve success in relation to their achievement in attaining personal goals such as self-fulfillment and goal attainment (Lerner, Brush \& Hisrich,, 1997; Still \& Timms, 2000). While Kalleberg and Leicht (1991) portrayed that women owned businesses are not likely to fail compared to their male counterparts, others (Cliff, 1998; Fasci \& Valdez, 1998) indicated that women perform less well on quantitative measures of performance such as job creation, sales turnover and profitability. In Islam, the maximization of profit alone is not sufficient for the women entrepreneurs as such, maximization of output must be accompanied by efforts directed to ensure spiritual health at the inner core of human consciousness and justice and fair play at all levels of human interaction (Chapra, 2000).

Murabaha Financing (MF): Murabaha financing entails an arrangement in which the entrepreneur requests the bank to acquire a particular good or equipment then the bank sells to the entrepreneur on a cost plus basis (Al-Mulhim, 2009). Among Islamic microfinance products, Murabaha financing has the largest outreach of 672,000 customers and total portfolio of assets of approximately US $\$ 413$ million (El-Zoghbi \& Tarazi, 2013). Murabaha financing is essentially an Islamic substitute to the commercial conventional interest based loan where a mark-up is an alternative to interest rate (Ahmed, 2010; El-Zoghbi \& Tarazi, 2013). In Islam, the encouragement to engage in legitimate trading practices such as Murabaha financing is clearly evident in $\mathrm{Al}$ Quran where Allah (SWT) says: "Allah has permitted trade and forbidden usury" (Al-Quran, 2:275). Furthermore, Al-Suyuti mentioned a Hadith narrated on the authority of Rafi' that: The Holy Prophet (Peace Be Upon Him (PBUH)) was asked: "Which are the best forms of income generation?" He (PBUH) replied, "A man's labor and every legitimate sale" (Cited in El-Gamal, 2000).

Suberu, Aremu and Popoola (2011) indicated that microfinance loans positively and significantly impact on small scale business performance via increasing overall market share, production efficiencies and competitiveness. Relating to micro enterprises, Hadisumarto (2013) saw that, in East Java, Islamic micro financing (Baitul Mal wat Tamwil) is effective in increasing income. However, Suresh, McKenzie and Woodruff (2008) in their empirical study found low returns to capital in women owned microenterprises. Suberu et al. (2011) suggested that future studies should explore the impact of alternative sources of finance available on 
small scale enterprise performance. This suggestion together with the preference for Islamic mode of financing present a new research gap for this study as to whether the Murabaha financing significantly influence the women entrepreneurs' performance. Such study has not been undertaken before. As such, this paper puts forward the following preposition:

Preposition 1: Murabaha financing (MF) is positively related to women entrepreneurs' business performance (WEBP).

Mudharabah Savings (MS): Mudharabah savings is similar to savings from the conventional banking point of view (Kasri \& Kassim, 2009), where reward paid on deposits is in the form of profit and not interest. The striking difference between profit and interest is that profit is the positive end result of trading which Allah (SWT) Has permitted as indicated in Al-Quran (2:275); "....That is because they say; trade is (just) like interest, but Allah has permitted trade and has forbidden interest." However, interest is excess over the principal amount in a loan contract. Savings enables depositors to meet two essential needs: to meet future consumption and to provide means for investment (Kasri \& Kassim, 2009). In support of Mudharabah savings, Al-Quran (17:29) explains that Muslims should "...not spend everything so that you became blameworthy and destitute". Mudharabah savings is therefore an arrangement in which entrepreneurs (savers) invest their deposits (savings) in the form of a contribution to be managed in the business of the micro finance institution which has to be Shariah compliant (Al-Mulhim, 2009; Ariff \& Rosly, 2011; El-Zoghbi \& Tarazi, 2013). The legal maxim derived from the Prophet (PBUH), that "profit comes with liability," justifies the difference between lawful profits, other forms of gain and entitlement only if there is liability or possibility of risk (Mohieldin, Iqbal, Rostom \& Fu, 2012). Additionally, the need for Islamic compatible services also presents a new research gap for this study as to whether the Mudharabah savings significantly influence the performance of women entrepreneurs. Therefore this paper posits the following preposition: Preposition 2: Mudharaba savings (MS) is positively related to women entrepreneurs' business performance (WEBP).

Training (TR): Training is an essential requirement in the development of strong and confident entrepreneurs who will facilitate the growth of their enterprises (Rao, 2014). Financial services alone cannot yield increased productivity (Ullah, Ahmad, Manzoor, Hussain, \& Farooq, 2012). It is therefore clear that micro-credit can only be effective when combined with training (Jalila, Mughalb, \& Isac, 2014). As explained by Berge, Marie, Nancy, Linda and Donna (2002), the dire need for improved performance requires ways through which training and education can be identified, measured and improved. According to Cheston and Kuhn (2002), training can significantly benefit the poor women entrepreneurs when it is tailored to match their existing skills and deal with their vital needs. The ethics of Islam strongly encourages Muslims to acquire training and skills by calling it fadhl (grace) of Allah (SWT) and highly praises those who strive in order to earn a living (Abeng, 1997). Islam calls on humans to use intellect and think as well as seek knowledge and discover the truth. This is evident in Al-Quran where Allah (SWT) says: "Proclaim! And thy Lord is the Most Bounteous; who taught by the pen, taught man what he knew not" (Al-Quran, 96:4-6). This paper therefore posits the following preposition:

Preposition 3: Training (TR) is positively related to women entrepreneurs' business performance (WEBP).

Social Capital (SC): Human beings as social creatures can only achieve their essential needs in groups, thus the desperate need for A'sabiyyah (i.e. one group shares same feelings, opinions, and values) which makes women entrepreneurs cooperate for common goals through social harmony (Chapra, 1999). Social capital is formally defined as the entirety of the actual and potential resources jointly found within, accessible through and obtained from a network of relationships controlled by individuals or social units (Nahapiet \& Ghoshal, 1998; Rhodes, Lok, Hung, Fang, 2008). In support of social capital, Allah (SWT) in Al-Quran (5:2) says: "And cooperate with each other in furthering righteousness and piety, but do not cooperate with each other in furthering evil and transgression". A relationship with fellow humans is thus prescribed in terms of corporation and that each person is a brother or sister to the other (Rice, 1999). Allah (SWT) in Al-Quran (49:13) says: "O mankind! We created from you from a single (pair) of a male and a female, and made you into nations and tribes, that you may know each other". Therefore, this paper posits the following preposition: Preposition 4: Social Capital (SC) is positively related to women entrepreneurs' business performance (WEBP). 
Self-Esteem (SE): Self-esteem entails views or evaluations towards oneself which an individual makes and maintains (Coopersmith, 1967; Wells \& Marwell, 1976). Duffy, Shaw and Stark (2000) emphasized that selfesteem varies in direction of relationship as well as intensity with the individual assessment of self-worth. Self-esteem is frequently considered as self-confidence, self-competence, self- respect, self-satisfaction and self-worth among others (Tharenou, 1979). Literature suggests that future researchers in the area of micro finance/or entrepreneurship could investigate whether self-confidence could be positively related to women entrepreneurs business performance either in the Nigerian context or other countries (Ekpe, 2012). In their study, on entrepreneurial characteristics and business success, Hassan, Ramli, and DeSa, (2014) recommends the inclusion of other independent variable such as self-esteem. Pinho and Desa (2014) further suggested that other personal attributes like self-esteem should be examined in relation to entrepreneurial performance. These suggestions present a new research gap for this study as to whether self-esteem significantly influences women entrepreneurs' business performance. From an Islamic point of view, the entrepreneur has a right to make choices and take decisions and the management and workers are in charge of their actions and cannot blame anyone such as the organization for their deficiencies (Abuznaid, 2009). This is evident in Al-Quran (53:38-39) where Allah (SWT) says: "That no bearer of burden will bear the burden of another, and there is not for man except that (good) for which he strives". Thus, the paper posits the following preposition:

Preposition 5: Self-Esteem (SE) is positively related to women entrepreneurs' business performance (WEBP).

Religiosity (RL): Chusmir and Koberg (1988) emphasized that religiosity plays a role in businesses entities by impacting on the operations of the business organization through shaping business organizations and personal lives. Disregarding religiosity can cripple a business and the stakeholders such as customers, employees and even competitors (Fatimah-Salwa, Mohamad-Azahari, \& Joni-Tamkin, 2013). Religiosity is an integral part of the Maqasid Al-Shari'ah (objectives of Islamic law) in safeguarding the Muslim's faith which is evident both in Tahsiniyyah (luxuries) and Daruriyyah (essentials) (Said, Ahmad, \& Yusuf, 2014). It is therefore arguable that Islamic microfinance related factors in order to achieve business performance depends on religious values of the Muslim women entrepreneurs. In Islam, business choices are guided by faith, or Iman, which essentially entails distinguishing between halal (ethical) and haram (unethical), appropriate and inappropriate, fair and unjust, good and bad intentions in business dealings (Abuznaid, 2009). Muslim entrepreneurs are therefore encouraged to have faith and fear Allah in their entrepreneurial endeavors (Zainul, Osman \& Mazlan, 2004). Based on the suggestion of Baron and Kenny (1986), the inclusion of a moderating variable (religiosity) is very important and thus justified. As such, it is arguable that Islamic microfinance related factors to achieve women entrepreneur's business performance can be moderated by religiosity. Therefore, the paper posits the following preposition:

Preposition 6: Religiosity (RL) moderates the relationship between Islamic Microfinance related factors and women entrepreneurs' business performance (WEBP).

\section{Figure 1: Conceptual Framework}

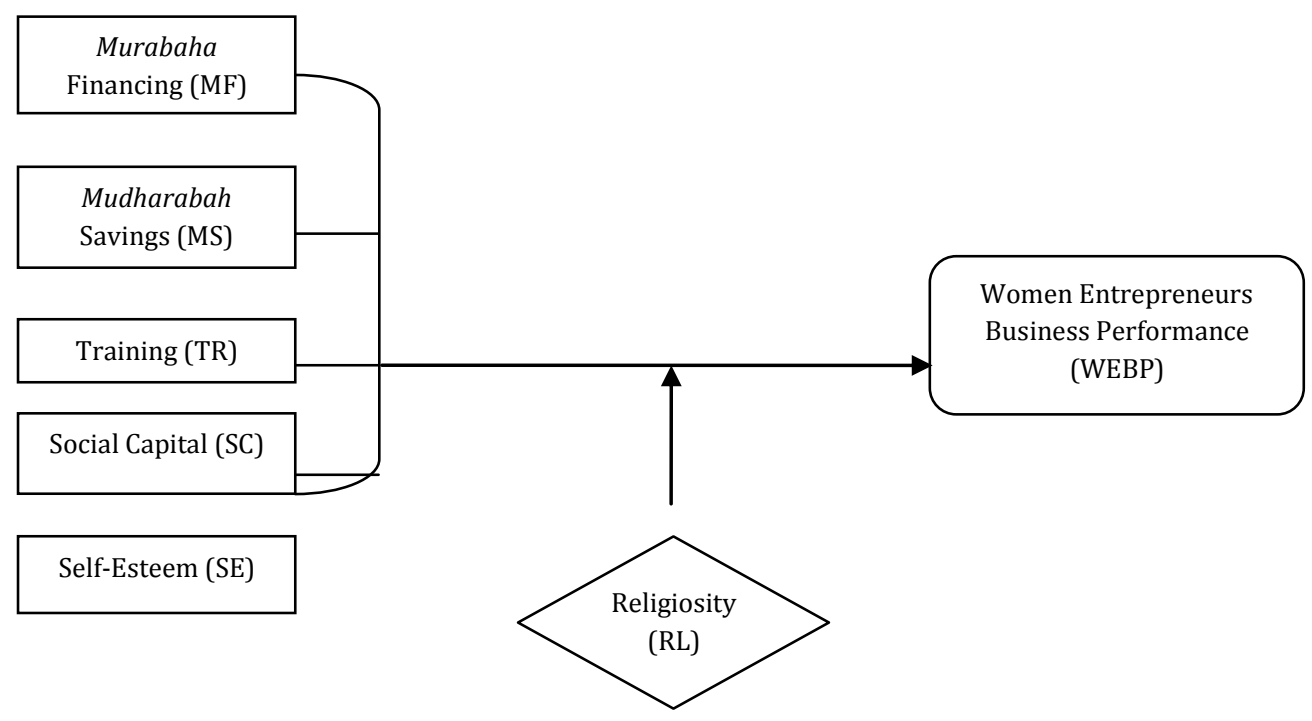


Research Framework: The relationship between Islamic micro finance related factors and women entrepreneurs business performance can be moderated by religiosity (Baele, Farooq \& Ongena, 2014; LePine \& Van Dyne, 1998; Adamu, Kedah \& Osman-Gani, 2011). Furthermore, the suggestions and the existence of inconsistent relationships between the independent variables and dependent variable in previous studies (Baron \& Kenny, 1986), warrant the use of religiosity as a moderating variable. This is a new dimension in the research framework to be tested against a Nigerian background. If Muslim women entrepreneurs are religiously connected, it is more likely that they will utilize Islamic micro finance services (Baele et al., 2014), which will result in better performance of their enterprises. The proposed framework therefore has seven constructs as illustrated in figure 1.

\section{Conclusion}

Although this study is an ongoing research, the development and establishment of Islamic banking and finance in Nigeria has significantly influenced the research. The provision of the research framework will be used to examine the relationship between Islamic microfinance related factors and women entrepreneurs' business performance and the validated findings will enhance decision making in Nigeria.

\section{References}

Abbas, K., Razak, D. A. \& Saad, N. M. (2014). The perception of micro-entrepreneurs and petty traders on conventional and Islamic microfinance: a case study of Pakistan. Journal of Islamic Finance, 3(1), 3848.

Abeng, T. (1997). Business ethics in Islamic context: Perspectives of a Muslim business leader. Business Ethics Quarterly, 7(3), 47-54.

Abuznaid, S. A. (2009). Business ethics in Islam: the glaring gap in practice. International Journal of Islamic and Middle Eastern Finance and Management, 2(4), 278-288.

Adamu, I. M., Kedah, Z. \& Osman-Gani, A. (2011, December). Entrepreneurial motivation, performance and commitment to social responsibility: A conceptual analysis on the influence of Islamic religiosity. Paper Prepared for the 10th International Conference of the Academy of HRD (Asia Chapter, (pp. 133). Kuala Lumpur, Malaysia.

Ahmed, A. (2010). Global financial crisis: An Islamic finance perspective. International Journal of Islamic and Middle Eastern Finance and Management, 3(4), 306-320.

Akinwumi, 0. (2000). Women entrepreneurs in Nigeria. Africa update newsletter, (Nigerian culture and society), Retrieved February 28th, 2015, from http://www.ccsu.edu/afstudy/upd7-3.htm\#, Women Entrepreneurs.

Al-Mulhim, N. K. (2009). Islamic funding of small business in Saudi Arabia: Unpublished master thesis, Open University of Malaysia.

Al-Quran, Arabic Text with corresponding English Meanings. (1997). Translated by Saheeh International. Riyadh: Abdulqasim Publishing House.

Alese, O. D. (2013). Women and poverty alleviation programs in Nigeria: The Napep approach. Academic Journal of Interdisciplinary Studies, 2(3), 515-521.

Ariff, M. \& Rosly, S. A. (2011). Islamic banking in Malaysia: Unchartered waters. Asian Economic Policy Review, 6(2), 301-319.

Baele, L., Farooq, M. \& Ongena, S. (2014). Of religion and redemption: Evidence from default on Islamic loans. Journal of Banking \& Finance, 44, 141-159.

Baron, R. M. \& Kenny, D. A. (1986). The moderator-mediator variable distinction in social psychological research: Conceptual, strategic, and statistical considerations. Journal of personality and social psychology, 51(6), 1173-1182.

Berge, Z., Marie, D. V., Nancy, B., Linda, D. \& Donna, S., (2002). The increasing scope of training and development competency. Benchmarking: An International Journal, 9(1), 43-61.

Berger \& Byvinie. (2003). Nature and determinants of the linkages between informal and formal sector enterprises in Nigeria. African Development Review, 13(1), 114-144.

Central Bank of Nigeria (CBN). (2005). Microfinance Policy, Regulatory and Supervisory Framework for Nigeria. Abuja, Nigeria. 
Chaganti, R. (1986). Management in women-owned enterprises. Journal of Small Business Management, 24(4), 18-29.

Chapra, M. U. (1999). Socioeconomic and political dynamics in Ibn Khaldūn's thought. The American Journal of Islamic Social Sciences, 16(4), 17-38.

Chapra, M. U. (2000). The Future of Economics: An Islamic Perspective. Leicester: The Islamic Foundation.

Cheston, S. \& Kuhn, L. (2002). Empowering women through microfinance. Unpublished draft, Opportunity International.

Chusmir, L. H. \& Koberg, C. S. (1988). Religion and attitudes toward work: A new look at an old question. Journal of Organizational behavior, 9(3), 251-262.

Cliff, J. E. (1998). Does one size fit all? Exploring the relationship between attitudes towards growth, gender, and business size. Journal of Business Venturing, 13(6), 523-542.

Hadisumarto, W. B. M. C. (2013). Enhancing the role of Islamic microfinance institution in poverty alleviation. Proceedings of the Roundtable Discussion on Financial Inclusiveness of the Poor: Beyond Microfinance, Universitas Islam Negeri Maulana Malik Ibrahim, Malang, Indonesia.

Coopersmith, S. V. (1967). Antecedents of self-esteem. San Francisco: Freeman.

Cuba, R., Decenzo, D. \& Anish, A. (1983). Management practices of successful female business owners. American Journal of Small Business, 8(2), 40-46.

Duffy, M. K., Shaw, J. D. \& Stark, E. M. (2000). Performance and satisfaction in conflicted interdependent groups: When and how does self-esteem make a difference? The Academy of Management Journal, 43(4), 772-782.

Ekpe, I. (2012). Women entrepreneurs' performance: microfinance factors with mediating effect of opportunity and moderating effect of attitude. Unpublished doctoral dissertation, Universiti Utara, Malaysia.

El-Gamal M. A. (2000). A basic guide to contemporary Islamic banking and finance. Available at http://www.nubank.com/islamic/primer.pdf

El-Zoghbi, M. \& Tarazi, M. (2013). Trends in Sharia-Compliant Financial Inclusion. CGAP Focus Note, 84, 1-12. Retrieved April 16th, 2015 from http://www.ruralfinance.org/fileadmin/templates/rflc/documents/Focus-Note-Trends-in-ShariaCompliant-Finanicial-Inclusion-Mar-2013.pdf

Fapohunda, T. M. (2012). Women and the Informal Sector in Nigeria: Implications for Development. British Journal of Arts and Social Sciences, 4(1), 35-45.

Fasci, M. A. \& Valdez, J. (1998). A performance contrast of male-and female-owned small accounting practices. Journal of Small Business Management, 36(3), 1-7.

Fatimah-Salwa, A. H., Mohamad-Azahari, A. \& Joni-Tamkin, B. (2013). Non-Financial performance of micro credit entrepreneurs: Does personal religious values matters? International Journal of Economics and Finance, 5(6), 34-45.

Halkias, D., Nwajiuba, C., Harkiolakis, N. \& Caracatsanis S. M. (2011). Challenges facing women entrepreneurs in Nigeria. Management Research Review, 34(2), 221-235.

Hassan, I. F., Ramli, A. \& Desa, N. M. (2014). Rural women entrepreneurs in Malaysia: What drives their success? International Journal of Business and Management, 9(4), 10-21.

Hisrich, R. D. \& Brush, C. G. (1987). Women entrepreneurs: A longitudinal study. In: N. C. Churchill, J. A. Hornaday, B. A. Kirchhoff, O. J. Krasner \& K. H. Vesper (Ed.) Frontiers in Entrepreneurship Research, pp. 187-199. Wellesley: Babson College.

Holmquist, C. \& Sundin, E. (1988). Women as entrepreneurs in Sweden: Conclusions from a survey. Frontiers of Entrepreneurship Research, 2, 626-642.

Jalila, M. F., Mughalb, Y. H. \& Isac, A. H. (2014). Effect of microfinance services towards women entrepreneurs development in Pakistan. International Journal of Business Management and Economic Studies, 1(1), 37-51.

Johnson, S. \& Storey, D. (1993). Male and female entrepreneurs and their businesses: A comparative study. In S. Allan and C. Truman (Ed.) Women in Business Perspectives on Women Entrepreneurs, pp. 7085. London: Routledge.

Kalleberg, A. L. \& Leicht, K. T. (1991). Gender and organizational performance: Determinants of small business survival and success. Academy of Management Journal, 34(1), 136-61.

Kasri, R. A. \& Kassim, S. H. (2009). Empirical determinants of saving in the Islamic banks: Evidence from Indonesia. J.KAU: Islamic Econ., 22(2), 3-23. 
Kiraka, R. N., Kobia, M. \& Katwalo, A .M. (2013). Micro, small and medium enterprise growth and innovation in Kenya: A case study of women enterprise fund. Investment Climate and Business Environment Research Fund, Report No. 47/13, Nairobi, Kenya. Retrieved November 8 ${ }^{\text {th }}$, 2014, from http://www.strathmore.edu/pdf/Final -Report-TA-11-056.pdf

LePine, J. A. \& Van Dyne, L. (1998). Predicting voice behavior in work groups. Journal of Applied Psychology, 83(6), 853-868.

Lerner, M., Brush, C. \& Hisrich, R. (1997). Israeli women entrepreneurs: An examination of factors affecting performance. Journal of Business Venturing, 12(4), 315-339.

Mohieldin, M., Iqbal, Z., Rostom, A. \& Fu, X. (2012). The role of Islamic finance in enhancing financial inclusion in Organization of Islamic Cooperation (OIC) Countries. Islamic Economic Studies, 20(2), 55-119.

Nahapiet, J. \& Ghoshal, S. (1998). Social capital, intellectual capital and the organizational advantage. Academy of Management Review, 23(2), 242-266.

Okojie, C., Monye-Emina, A., Eghafona, G. \& Ehiakhamen, J. O. (2010). Nigeria Strategy Support Program. International Food Policy Research Institute. Abuja, Nigeria.

Pinho, J. C. \& DeSa, E. S. (2014). Personal characteristics, business relationships and entrepreneurial performance: some empirical evidence. Journal of Small Business and Enterprise Development, 21(2), 284-300.

Rao, S. (2014). Nurturing entrepreneurial women: Insights from a developing country. Journal of Entrepreneurship in Emerging Economies, 6(3), 268-297.

Rhodes, J., Lok, P., Hung, R. Y. \& Fang, S. (2008). An integrative model of organizational learning and social capital on effective knowledge transfer and perceived organizational performance. Journal of Workplace Learning, 20(4), 245-258.

Rice, G. (1999). Islamic ethics and the implications for business. Journal of Business Ethics, 18(4), 345-358.

Said, J., Ahmad, M. \& Yusuf, S. N. S. (2014). Effectiveness of capital assistance program: Evidence from Malaysia. Research Journal of Applied Sciences, Engineering and Technology, 8(4), 488-495.

Shane, S. (2003). A General Theory of Entrepreneurship: The Individual-Opportunity Nexus. UK: Edward Elgar.

Still, L. V. \& Timms, W. (2000). Women's business: The flexible alternative work style for women. Women in Management Review, 15(5/6), 272-282.

Suberu, O. J., Aremu, O. S. \& Popoola, E. G. (2011). The impact of microfinance institutions on the development of small scale enterprises in Nigeria. Journal of Research in International Business Management, 1(8), 251-257.

Suresh, D., McKenzie, D. \& Woodruff, C. (2008). Returns to capital in microenterprises: Evidence from a field experiment. Quarterly Journal of Economics, 123(4), 1329-72.

Tharenou, P. (1979). Employee self-esteem: A review of the literature. Journal of Vocational Behavior, 15(3), 316-346.

Ullah, H., Ahmad, Z. M., Manzoor, S. R., Hussain, M. \& Farooq, M. A. (2012). Problem faced by women entrepreneurs in Kohat City of Khyber Pakhtunkhwa, Pakistan. International Journal of Human Resource Studies, 2(1), 1-14.

Verheul, I., Stel, A. V. \& Thurik, R. (2006). Explaining female and male entrepreneurship at the country level. Entrepreneurship and regional development, 18(2), 151-183.

Wells, L. E. \& Marwell, G. (1976). Self-esteem. London: Sage.

Zainul, N., Osman, F. \& Mazlan, S. H. (2004). E-Commerce from an Islamic perspective. Electronic Commerce Research and Applications, 3(3), 280-293. 